\title{
Water Supply Basins of São Paulo Metropolitan Region: Hydro-Climatic Characteristics of the 2013-2015 Water Crisis
}

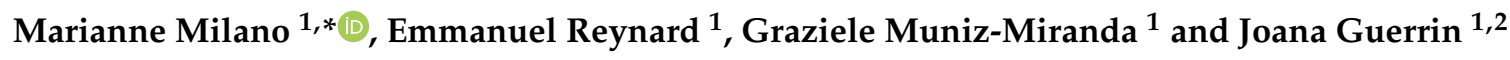 \\ 1 Institute of Geography and Sustainability, University of Lausanne, Geopolis Building, \\ CH-1015 Lausanne, Switzerland; emmanuel.reynard@unil.ch (E.R.); gmunizmiranda@gmail.com (G.M.-M.); \\ joana.guerrin@unil.ch (J.G.) \\ 2 CHROME, University of Nîmes, 30000 Nîmes, France \\ * Correspondence: marianne.milano@unil.ch; Tel.: +41-21-692-30-77
}

Received: 29 August 2018; Accepted: 23 October 2018; Published: 25 October 2018

check for updates

\begin{abstract}
São Paulo metropolitan region experienced an acute water crisis between 2013 and 2015. According to the Brazilian and international press, it was due to climatic, anthropogenic, and water management factors. This paper assesses the hydro-climatic characteristics of the crisis by focusing on the Alto-Tietê basin and the headwater of the Piracicaba-Capivari-Jundiaí (PCJ) basin that supply $70 \%$ of the water consumed in the metropolis. Based on 16 rain-gauge stations, 5 runoff-gauge stations, and several statistical analyses carried over the 1951-2015 period, this assessment shows that the 2013-2015 hydro-climatic crisis resulted from a large number of days without rain in the north of the Alto-Tietê basin and to less intense precipitation events in the headwaters of the PCJ basin during the austral spring 2013 and the year 2014. It also defines a return period of 98 years for observed river flows in 2014. Despite the rare nature of this hydrological drought, the need for efficient water saving policies is brought forward.
\end{abstract}

Keywords: São Paulo; Brazil; water scarcity; hydrological drought; low-flow frequency; low-flow threshold

\section{Introduction}

Regarding water resources, Brazil has a privileged position. It holds $12 \%$ of the world's freshwater resources and has a water availability of 41,603 $\mathrm{m}^{3} /$ inhabitants/year [1,2]. This value varies from $634,887 \mathrm{~m}^{3}$ /inhabitants/year in the Amazon region to $1460 \mathrm{~m}^{3}$ /inhabitants/year in the Northeast $[1,2]$. Freshwater resource-distribution is indeed extremely unequal: $70 \%$ of the available freshwater is located in the Amazon basin, where less than 7\% of the population live, while more than half of the Brazilian population lives in catchments of the Atlantic coast and face water scarcity problems [1,3]. Water scarcity issues derive from a semiarid climate, intermittent flows, and highly urbanized areas in the northeastern States, high water demands for irrigation purposes in the central and southern States, and high industrial and urban demands combined with water quality degradation in southeastern Brazil [1,3]. The southeastern state of São Paulo was notably affected by a severe water crisis that began in October 2013 and extended to the neighboring states of Rio de Janeiro and Minas Gerais in 2014 and 2015 [4,5]. Surface- and ground-water resources were depleted due to deficient rainy seasons and high temperatures [6,7]. This resulted in urban water supply shortages, massive losses in the 2014 agricultural harvest, and imperiled hydropower generation [7,8]. The water crisis was particularly acute in São Paulo's Metropolitan Region (SPMR), South America's largest metropolis, where $10 \%$ of Brazilians live (nearly 20 million in 2014) [9] and 17\% of the national gross domestic product is produced [1]. 
According to the Brazilian and international press, the SPMR faced its greatest water crisis due to interconnected natural, anthropogenic and water management factors, see e.g., [10-14]. The meteorological cause, at a continental scale, was the persistence of a wide and intense mid-atmosphere blocking high over Southeastern Brazil during the austral summer 2014, i.e., a high pressure area with a barotropic structure that blocked the passage of cold fronts from the south and moisture from the Amazon region thus impeding deep cloud formation [6,15,16]. It lasted for 45 days, when it usually lasts for 7 to 8 days $[7,17]$. At the regional scale, it resulted in an exceptionally dry event with a lack of rainfall during several consecutive weeks and temperatures above average during the austral summer 2014 [18]. In 2014, the state of São Paulo recorded the driest and warmest year since 1961 (830 mm in comparison to $1681 \mathrm{~mm}$ on average over the 1981-2010 climatological mean [18,19]; mean maximum temperature of $31.4{ }^{\circ} \mathrm{C}$ in comparison to $28.7^{\circ} \mathrm{C}$ on average during the 1961-2015 period [7]). This persistent climatic drought enhanced a sharp decline in the water flowing into the reservoirs that supply water to the metropolis. From December 2013 to January 2015, water inflows were, on average, 70\% and 35\% below the historical mean and historical minimum inflow, respectively [20]. Combined with high evaporation rates, as reservoirs are open-air, and water withdrawals, it resulted in dangerously low water levels, fluctuating around $5-15 \%$ of their full capacity $[20,21]$. The metropolis rising population exacerbated the vulnerability of the region: there was a six-fold increase between 1950 and 1980, and a growth rate of 74.3\% between 1980 and 2015 [22]. In addition, water pollution from domestic and industrial effluents flowing into water bodies reduced water availability [23,24]. During the crisis, $10 \%$ of wastewater was not collected [23]. Some authors also pointed out that deforestation at the continental and regional scale added to the water crisis by affecting precipitation distribution and soil water retention capacities [25-28]. Finally, studies have called on the importance of socio-political drivers in the water crisis. Supplying water in sufficient quantity and quality has become a political issue in many localities of SPMR [29] that aggravated during the crisis $[8,10,30]$. During the water crisis, the water and sanitation management company of São Paulo State (SABESP-Saneamento Básico do Estado de Sao Paulo) set two main measures (Jerson Kelman, director of SABESP, personal communication, 8 August 2016). The first one consisted in offering discounts on water pricing to reduce water consumption: the more people or industries saved water, the more they saved on their water bill. The second measure involved decreasing pressure in the pipes to reduce leakages, estimated at 28\% (Head of the Integrated Planning Department, personal communication, 8 August 2016). This measure reduced the ability of water to arrive uphill and dried taps in the periphery of the city $[27,30]$. Unfortunately, the poorest districts are in the outskirt of the city, water connections are precarious and houses are not always equipped with water towers, although they are legally mandatory in Brazil. Hence, Millington (2018) argues that the water crisis was "produced by the combination of existing inequities in city's water infrastructure and the differentiated abilities of residents to store water" [30]. Soriano et al. (2016) also claim the lack of information from the authorities about the water crisis and on the state of the Cantareira system until it reached a critical level, i.e., when water had to be tapped from the dead volume for the second time [8].

Given the substantial impacts of the droughts, the number of people affected by water supply restrictions, and the unsatisfactory water management options taken, it is essential to grasp the hydro-climatic characteristics of this water crisis. Several authors have explored the atmospheric origins of São Paulo's water crisis see e.g., $[6,15,16,18]$. Others have analyzed its hydro-climatic context at the scale of the southeastern region [7,31] or the State of São Paulo [18]. A comparison of the climate of the cities of Monte Alegre do Sul, located in the north of the metropolis, and of São Paulo during the water crisis was also carried out [32]. Our study is complementary to these previous hydro-climatic studies by focusing on the two main catchments that supply water to SPMR. This paper offers a detailed hydro-climatic analysis of this area based on a large number of historical records (data available for 16 rain-gauge stations and 5 runoff-gauging stations) and usual statistical tools in order to examine the spatial and temporal variability of precipitation and runoff over the 1951-2015 period, address droughts' conditions in these two regions and evaluate the return period of observed 
runoff series. This paper also aims to bring light on the rare nature of the drought event that affected the SPMR between 2013 and 2015 but also on the vulnerability of the metropolis to droughts.

\section{Study Area}

This study focuses on the two main regions that supply water to the SPMR: the Alto-Tietê basin and the headwater of the Piracicaba-Capivari-Jundiaí (PCJ) basin (Figure 1a).

The SPMR is Brazil's most important economic and industrial center. It occupies an area of $7946 \mathrm{~km}^{2}$, of which one third is urbanized [33-35]. Its population rose from 2 million inhabitants in 1940 to 12.6 million in 1980 and to nearly 20 million in 2014, making it the world's fourth most populous metropolis nowadays [9]. Rapid urban sprawl, including the expansion of informal settlements in protected areas, and industrial growth generated intense water demands. In 2004, total water demand rose to $86.4 \mathrm{~m}^{3} / \mathrm{s}$, which $79.3 \%$ came from the urban sector, $16.6 \%$ from the industrial sector and $4.2 \%$ from the agricultural sector [36]. An extensive network of water infrastructures has been implemented over the years, in particular, three main systems that provide $70 \%$ of the water consumed in SPMR: the Guarapiranga, the Billings and the Cantareira systems.
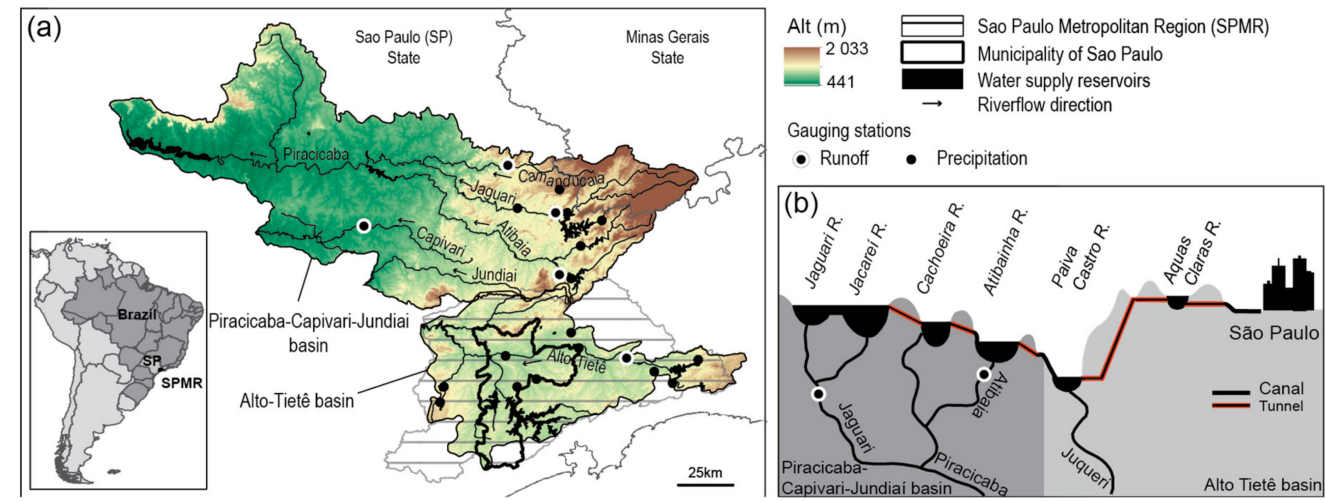

Figure 1. (a) Localization of São Paulo metropolitan region (SPMR) and its main water supply reservoirs in the Alto-Tietê and Piracicaba-Capivari-Jundiaí basins; (b) Simplified representation of the Cantareira system (R: Reservoir).

The Guarapiranga and Billings reservoirs, respectively built in 1908 and 1925, are located in the Alto-Tietê basin (Figure 1a). They supply water to 5.6 million people in the southern and southeastern parts of the metropolis. However, these open-air reservoirs face serious water pollution problems due to the expansion of urban slums with no sewage or solid waste collection system on their shores. The Alto-Tietê basin encompasses 35 out of 39 municipalities of the SPMR and is home to around $98.9 \%$ of its population [37]. Bordered in the south by the Serra do Mar mountains, its northeastern side by the Serra da Cantareira and its northwestern side by the Paranapiacaba mountain range, the Tietê River drains an area of $5986 \mathrm{~km}^{2}$ in its upper part. It is characterized by a tropical climate with mean annual temperatures of $17.8{ }^{\circ} \mathrm{C}$ and precipitation of $1430 \mathrm{~mm} /$ year (1951-2015 period) [33].

In the early 1960s, water supply difficulties occurred. Starting in 1966, an interbasin water transfer system, the Cantareira System, was developed in the north of SPMR (Figure 1b). It was impounded in 1976 and became operational in 1981. Formed of six open-air reservoirs that cover an area of $22,579.5 \mathrm{~km}^{2}$, it is one of the world's biggest water production system. The first four reservoirs collect water from the headwaters of the Piracicaba-Capivari-Jundiaí (PCJ) basin and have a total effective volume of $973.9 \mathrm{Hm}^{3}$ [4,38] (Figure 1b). Tunnels, canals and pumps drive water to the Alto-Tietê basin to supply 8.1 million people in the northern and central part of SPMR. The Cantareira system is managed by SABESP, the water and sanitation management company of São Paulo State. Water allocation between the SABESP and the PCJ river basin committee depends on water transfer authorization adopted in 2004. Minimum and maximum allocation of $24.8-31 \mathrm{~m}^{3} / \mathrm{s}$ for SPMR and $3-5 \mathrm{~m}^{3} / \mathrm{s}$ for the PCJ basin were defined under normal hydrological conditions, along with operational 
rules to be applied during drought episodes $[20,39,40]$. As an example, in March 2014, the SABESP extracted $33 \mathrm{~m}^{3} / \mathrm{s}$ from the Cantareira system and, as a result of the drought, it gradually had to reduce water extraction, reaching an extraction grant of $13.5 \mathrm{~m}^{3} / \mathrm{s}$ in early 2015 [20].

\section{Material and Methods}

\subsection{Data}

Daily precipitation and runoff data available on the Alto-Tietê basin and the headwaters of the PCJ catchment were provided by the Departamento de Águas e Energia Elétrica (DAEE) of São Paulo State and the National Water Agency (Agência Nacional de Águas, ANA), for the period 1930-2017. Gauging stations that had records during the 2013-2015 period, and less than 10\% gaps for precipitation, were selected, reducing the analysis to the 1951-2015 period. In the Alto-Tietê basin, 10 precipitation stations and one runoff station monitoring the Alto-Tietê River were used while in the headwaters of the PCJ basin, 6 precipitation stations and 4 runoff stations monitoring the Camanducaia, Jaguari, Atibaia and Capivari rivers were considered (Figures 1 and 2). For the Jaguari and Atibaia rivers, the gauging stations are respectively located at the outlet of the two first reservoirs (Jaguari and Jacareí) and the fourth reservoir (Atibainha) of the Cantareira System (Figure 2). Based on this data, daily, monthly and annual analyses were carried out but, for synthesis purposes, results will be presented at a decadal or seasonal time-step.

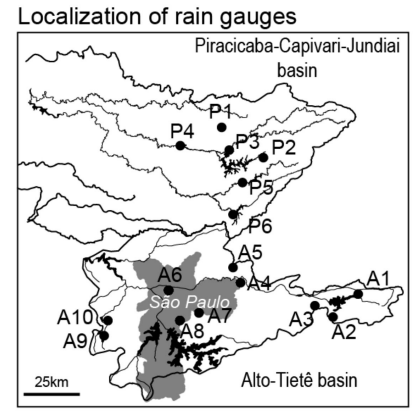

\begin{tabular}{cccc}
\hline Station & Period & $\begin{array}{c}\text { Data gaps } \\
(\%)\end{array}$ & $\begin{array}{c}\text { Annual mean } \\
\text { (mm for rain; } \mathrm{m}^{3} / \mathrm{s} \text { for runoff) }\end{array}$ \\
\hline Rain gauges - Piracicaba-Capivari-Jundiai basin & \\
P1 & $1951-2015$ & 5.3 & 1596.1 \\
P2 & $1952-2015$ & 1.7 & 1508.3 \\
P4 & $1951-2015$ & 0.3 & 1556.3 \\
P5 & $1951-2015$ & 4.4 & 1439.5 \\
P6 & $1951-2015$ & 7.1 & 1389.0 \\
\hline Rain gauges - Alto-Tietê basin & $1951-2015$ & 0.0 & 1402.0 \\
A1 & $1951-2015$ & 0.8 & 1236.4 \\
A2 & $1951-2015$ & 5.9 & 1850.4 \\
A3 & $1951-2015$ & 2.6 & 1313.8 \\
A4 & $1951-2015$ & 1.5 & 1331.5 \\
A5 & $1951-2015$ & 0.8 & 1434.4 \\
A6 & $1951-2015$ & 6.0 & 1330.2 \\
A7 & $1951-2015$ & 2.8 & 1394.2 \\
A8 & $1951-2015$ & 0.0 & 1472.3 \\
A9 & $1951-2015$ & 0.8 & 1404.8 \\
A10 & $1951-2015$ & 0.1 & 1384.4 \\
\hline Runoff gauges ${ }^{*}$ & & & 6.8 \\
Camanducaia & $1951-2015$ & 0.0 & 14.1 \\
Jaguari & $1971-2015$ & 20.7 & 2.5 \\
Atibaia & $1971-2015$ & 20.9 & 10.5 \\
Capivari & $1952-2015$ & 10.9 & \\
Alto-Tietê & $1965-2015$ & 3.8 & \\
\hline
\end{tabular}

Figure 2. Dataset availability. ${ }^{*}$ Data gaps and annual means are evaluated over the period for which data is available.

\subsection{Seasonal Patterns of Precipitation and Runoff Series}

Seasonal rainfall patterns, i.e., changes in the beginning and ending month of the rainy or dry season, were analyzed at a decadal time step. According to Erpicum et al. (1987), the dry season begins when the probability of having a dry day (precipitation $<1 \mathrm{~mm}$ ) belonging to a dry event of at least seven days is greater than the probability of having a wet day (precipitation $\geq 1 \mathrm{~mm}$ ) [41]. Based on this assumption, the evolution of these two types of days were computed and presented on a same graph over 5-day periods. The dry period is defined when the curve of the percentage of dry days belonging to a dry event of at least seven days is above the curve of the percentage of wet days, and vice versa [42]. 
Pardé's coefficients [43] were used to define the hydrological regime of the Alto-Tietê, Camanducaia, and Capivari rivers. They are based on the ratio of mean monthly runoff to mean annual runoff on a multiannual basis. The regimes of the Jaguari and Atibaia rivers were not explored as gauging stations are located at the outlet of reservoirs of the Cantareira system (Figure 1), and river flow dynamics are influenced by reservoir management options.

\subsection{Trends in Hydroclimatic Series}

The stationarity of precipitation and runoff monthly series was addressed by applying the statistical tests of Pettitt [44], Lee and Heghinian (L\&H) [45] and Buishand [46] as well as the segmentation of Hubert et al. [47], using the free software Khronostat [48]. These tests aim to detect ruptures, i.e., segments of the time series with significant different means, or variance in the case of Pettitt test. If no rupture is detected, the stationarity of the series is accepted. These tests were applied to all precipitation and runoff series, except downstream the main reservoirs of the Cantareira system where river flows are influenced by reservoir management.

\subsection{Hydroclimatic Variability}

The Standardized Precipitation Index (SPI) [49,50] was used to characterize drought or abnormal wet events. This index is based on the long-term precipitation record fitted to a gamma distribution, which is transformed into a normal distribution so that the mean SPI for the desired location and period is zero [51]. It is then computed by dividing the difference between the normalized monthly, seasonal, or annual precipitation and its long-term mean by the standard deviation (Equation (1)). It provides information on the spatial distribution of precipitation and indicates areas affected by low and heavy precipitation events over time. In this study, the SPI was computed for each station at an annual time-step over the 1951-2015 period (Equation (1)).

$$
S P I=\frac{P_{\text {year }}-\overline{P_{1951-2015}}}{\sigma_{1951-2015}}
$$

with $P$, the normalized annual precipitation (in mm); $P_{1951-2015}$, the long-term annual mean and $\sigma$, the precipitation standard deviation over the studied period.

The number of wet days and the average amount of precipitation on wet days, monitored at each station, for each year, were used to quantitatively characterize changes in total rainfall.

\subsection{Intensity of Drought Events}

Droughts are here explored from a hydrologic point of view. They are viewed as a period of time during which there is a lower availability of water in the hydrological cycle than the long-term average [52].

The threshold level method was applied to determine the mean duration, deficit volume and intensity of precipitation anomalies and hydrological droughts [53,54]. This method assumes that a drought is characterized by precipitation and discharge falling below a threshold level until it is exceeded again [53]. For each station, daily thresholds specific for each Julian day derived from the 80th percentile of daily precipitation/flow duration curves were applied to daily precipitation/runoff series.

The 80th percentile was chosen as it is recommended and often used as a standard in drought analysis for perennial rivers [55,56]. Daily flow duration curves were defined based on the "thirty-day moving window" threshold level approach, which is recommended to smooth within-year fluctuation of hydro-meteorological time series and define suitable threshold values [53]. Based on this approach, daily thresholds specific for each Julian day were computed from the flow duration curve defined from the set of 30-days observations centered on that particular day [54]. It should also be noted that before doing any analysis, precipitation series were smoothed using a 30-day moving average due to their dynamic nature [54]. 
The threshold level approach identifies any short- or long-term drought events. Identified drought events were pooled together if less than 10 days occurred between two consecutive events or excluded if they lasted less than 15 days.

\subsection{Frequency of Drought Events}

Finally, a low-flow frequency analysis [57] was performed to determine the frequency and severity of the drought event that occurred between 2013 and 2015.

For each runoff gauging station, a low flow frequency curve was constructed based on series of annual flow minima (one sole value from every year of record). The latter were extracted from annual series of 7-day average flows, less sensitive to day-to-day variations and measurement errors $[57,58]$. Several probability distribution functions most suitable for fitting the shape of the data were examined using the software EasyFit [59]. The distribution functions of Gumbel, Weibull and LogPearson Type III, as well as the Generalize Extreme Value (GEV) function, were explored as they are frequently used in connection with low flows see e.g., $[57,60,61]$. The statistical tests of Chi-Square [62], Anderson-Darling [63], and Kolmogorov Smirnov [64], as well as the root mean square error, were mobilized to identify which distribution best fitted the datasets. Three low-flow indices were finally extracted to determine the low-flow frequency and judge of the severity of the 2013-2015 drought event:

- 7Q2, annual 7-day minimum flow with a two-year recurrence interval (non-exceedance probability of 50\%) [58];

- 7Q10, annual 7-day minimum flow with a ten-year recurrence interval (non-exceedance probability of $10 \%$ ) [58];

- $\quad$ Return period of observed 7-day flow minima.

\section{Results}

\subsection{Seasonal Patterns of Precipitation and Runoff}

The analysis of the beginning and ending of the dry season shows that the Alto-Tietê basin and the headwater of the PCJ basin are characterized by a dry season extending from April to mid-October (Figure 3a). During the dry season, more than 30\% of dry days belong to a dry event of at least seven days and there are less than $20 \%$ of wet days. The driest months are July and August during which $65-75 \%$ and $70-80 \%$ of dry days belong to a dry event of at least seven days in the Alto-Tietê basin and the headwater of the PCJ basin, respectively, and there are less than $20 \%$ and $10 \%$ of wet days, respectively. In both basins, the wet season extends from mid-October to March. The wettest months are December, January and February (Figure 3a). They are characterized by $40-50 \%$ of wet days and less than $10 \%$ of dry days belonging to a dry event lasting at least seven days.

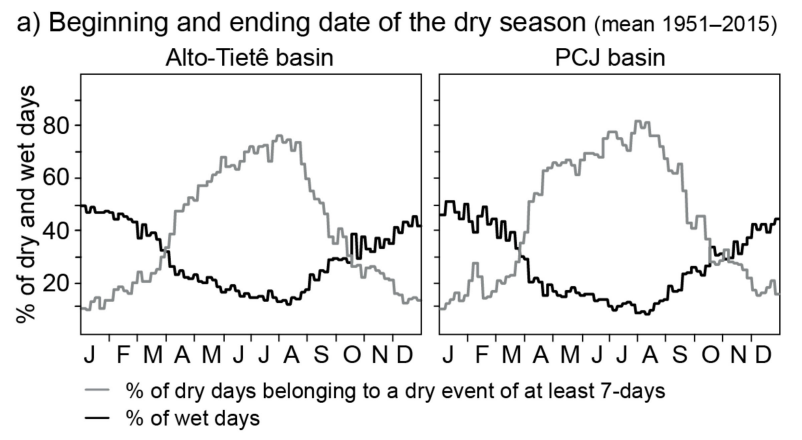

b) Hydrological regimes

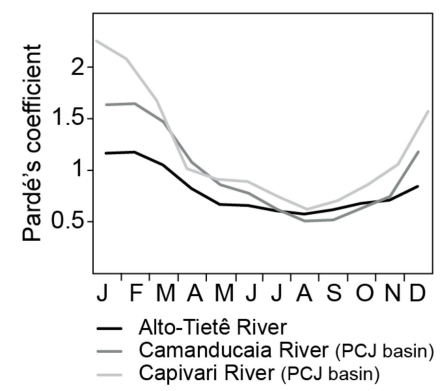

Figure 3. Mean seasonal pattern of (a) precipitation and (b) runoff in the Alto-Tietê basin and the headwaters of the Piracicaba-Capivari-Jundiaí (PCJ) basin for the 1951-2015 period. 
The Alto-Tietê, Camanducaia and Capivari rivers have a pluvial hydrological regime, which follows these seasonal patterns (Figure 3b). Mean monthly river flows are high from January to February $\left(15.5 \mathrm{~m}^{3} / \mathrm{s}, 11.4 \mathrm{~m}^{3} / \mathrm{s}\right.$ and $14.5 \mathrm{~m}^{3} / \mathrm{s}$ on average over the 1951-2015 period, respectively) and low from May to October, with the lowest values generally observed in August $\left(7.7 \mathrm{~m}^{3} / \mathrm{s}, 3.5 \mathrm{~m}^{3} / \mathrm{s}\right.$, $4 \mathrm{~m}^{3}$ /s on average over the 1951-2015 period, respectively).

Nonetheless, three main changes in the seasonal pattern of precipitation emerged. The wet character of the 1981-1990 decade could first be highlighted. More wet days and less dry days belonging to a dry event of at least seven days than the 1951-2015 average were recorded during the dry season, even during the driest months July and August (Figure 4A(a),B(a)).

The dry nature of the decades 1971-1980, 2001-2010, and 2011-2015 could also be outlined. In the former cases, more dry days belonging to a dry event of at least seven days were recorded during the wet season compared to the 1951-2015 average (Figure 4A(b),B(b) illustrated by the decade 2001-2010). The curve of the percentage of dry days belonging to a dry event of at least seven days is even above the curve of the percentage of wet days at times, highlighting short dry periods prior the dry season. For the latter case, the dry season was identified as more intense than the long-term average with (i) a dry season ending in mid-November in the Alto-Tiete (Figure 4A(c)), (ii) 70-80\% and 80-90\% of dry days belonging to a dry event of at least seven days in August, in the Alto-Tiete basin (Figure 4A(c)) and the headwater of the PCJ basin (Figure 4B(c)), respectively, (iii) $40 \%$ of dry days still belonging to a dry event of at least seven days in October and November in both basins, and (iv) less than $10 \%$ of wet days in August and less than 20\% in September and October in both basins.

\title{
(A) Seasonal patterns in the Alto-Tietê basin
}

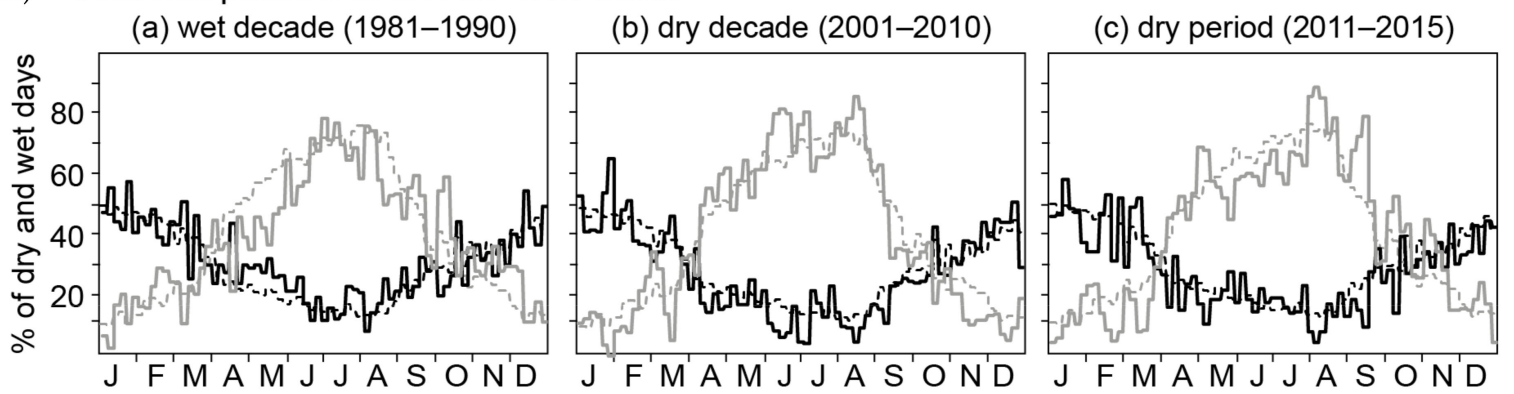

(B) Seasonal patterns in the headwaters of the PCJ basin

(a) wet decade (1981-1990)

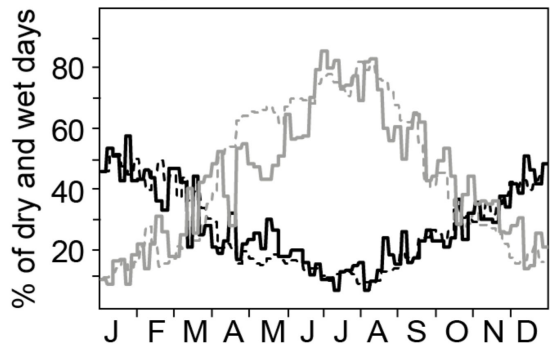

(b) dry decade (2001-2010)

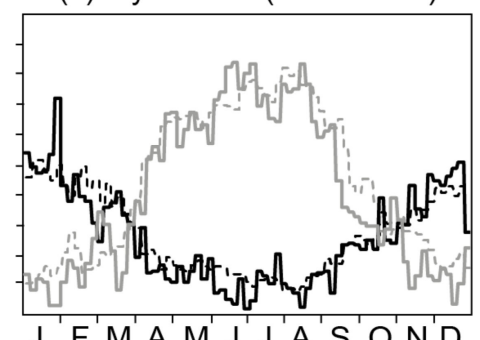

(c) dry period (2011-2015)
$\%$ of dry days belonging to a dry event of at least 7 days
— considered decade
-.... long-term mean (1951-2015)

\author{
$\%$ of wet days \\ — considered decade \\ -.... long-term mean (1951-2015)
}

Figure 4. Specific precipitation seasonal patterns that emerged from the 1951-2015 average in (A) the Alto-Tietê and (B). PCJ basins: (a) wet decade (1981-1990) due to more wet days and less dry days during the dry season, (b) dry decades (1971-1980 and 2001-2010) due to more dry days during the wet season, and (c) dry period (2011-2015) due to a longer and more intense dry season.

\subsection{Long Term Trends in Precipitation and Runoff Since 1951}

Based on the four statistical tests, ruptures in precipitation series were detected for two rain gauges (P5 and P6) located in the south of the PCJ basin. The ruptures highlight an increase of precipitation by 
13\% in P5 since 1988, and by 20\% in P6 since 1975 (not shown). No rupture, i.e., no long-term trends, were identified for other precipitation series recorded in the Alto-Tietê and PCJ basins.

Regarding runoff series, distinct results were obtained. A decreasing trend in monthly runoff was observed for the Alto-Tietê River as well as a rupture in 2000, highlighting a 50\% decrease in annual stream flows. For the Camanducaia River, a rupture was detected in 1971 by the statistical test of Pettit and in 2013 by the statistical test of L\&H. Between 1951-1971 and 1972-2013, annual runoff records increased by $16.9 \%$ whereas since 2013 they decreased by two and a half time (183\%). Finally, all tests detected a rupture in 1981 for the Capivari River: annual runoff records have doubled since then.

\subsection{Spatial and Temporal Distribution of Precipitation Since 1951}

Figure 5 shows the distribution of decadal SPI based on annual SPI values computed for each rain gauges between 1951 and 2015. Dry and wet decades are defined by negative and positive values, respectively. Based on this figure, three main precipitation events can be identified, as described below.

First, a dry spell affecting the whole study area during the 1961-1970 decade can be seen (Figure 5). A shortfall in precipitation is recorded by 11 out of 16 stations. In five stations, located in the Alto-Tietê basin, the number of low intensity precipitation events (1-10 mm/day) increased at the expense of moderate intensity events (11-40 mm/day; not shown). In the other stations, a decrease in the mean number of wet days by 8 to 20 days in the Alto-Tietê basin, and by 7 to 13 days in the headwaters of the PCJ basin were registered. This decade is also characterized by two severely dry years: 1963 $(-2.32 \leq \mathrm{SPI} \leq-1.18$ in the Alto-Tietê basin and $-2.32 \leq \mathrm{SPI} \leq-0.56$ in the headwaters of the PCJ basin) and 1968 ( $-2.39 \leq \mathrm{SPI} \leq-1.04$ and $-1.83<\mathrm{SPI}<-0.6$, respectively). In the Alto-Tietê basin, all stations recorded a decrease in precipitation by 25-35\% in 1963 and 20-30\% in 1968 (not shown). In the headwaters of the PCJ basin, precipitation decreased on average by $25 \%$ and $35 \%$, respectively.

Second, a wet event affecting the whole study area during the 1981-1990 decade is observed (Figure 5). An excess in precipitation is recorded by 12 out of 16 stations. More moderate intensity events and a day or two of additional extreme events $(>41 \mathrm{~mm})$ were measured in the Alto-Tietê basin (not shown). In the northern part of the basin and in the headwaters of the PCJ basin, the mean number of wet days increased by 10 to 20 days, and 6 to 14 days, respectively. In addition, the wettest year of the 1951-2015 period was recorded by all stations during this decade, in $1983(1.24 \leq \mathrm{SPI} \leq 3.99$ in the Alto-Tietê basin and $2.46 \leq$ SPI $\leq 3.75$ in the headwaters of the PCJ basin). On average, annual precipitation reached $2167.3 \mathrm{~mm}(+22 \%$ to $69 \%$ compared to the 1951-2015 annual average, depending on the station; Figure 2) and $2457.1 \mathrm{~mm}(+50 \%$ to $86 \%$; Figure 2$)$ in the stations of the Alto-Tietê and PCJ basins, respectively.

Finally, the headwaters of the PCJ basin and the northern part of the Alto-Tietê basin are characterized by a dry spell during the 2011-2015 period, while normal to wet conditions are identified in the southern and eastern part of the latter (Figure 5). One quarter of precipitation events were less intense and more than half were of low intensity $(1-10 \mathrm{~mm})$ in the headwaters of the PCJ basin, while in the northern part of the Alto-Tietê basin, the number of wet days decreased by 6 to 35 days (not shown). In the headwaters of the PCJ basin, the 2011-2015 period was also characterized by three significantly dry years: 2013, 2014 and 2015, for which mean annual precipitation amounted for $1303.6 \mathrm{~mm}(-12.5 \%$ compared to the 1951-2015 annual mean), $922.6 \mathrm{~mm}(-38 \%)$ and $1359.3 \mathrm{~mm}(-8.8 \%)$, respectively. The year 2014 was even identified as one of the driest years of the 1951-2015 period. 

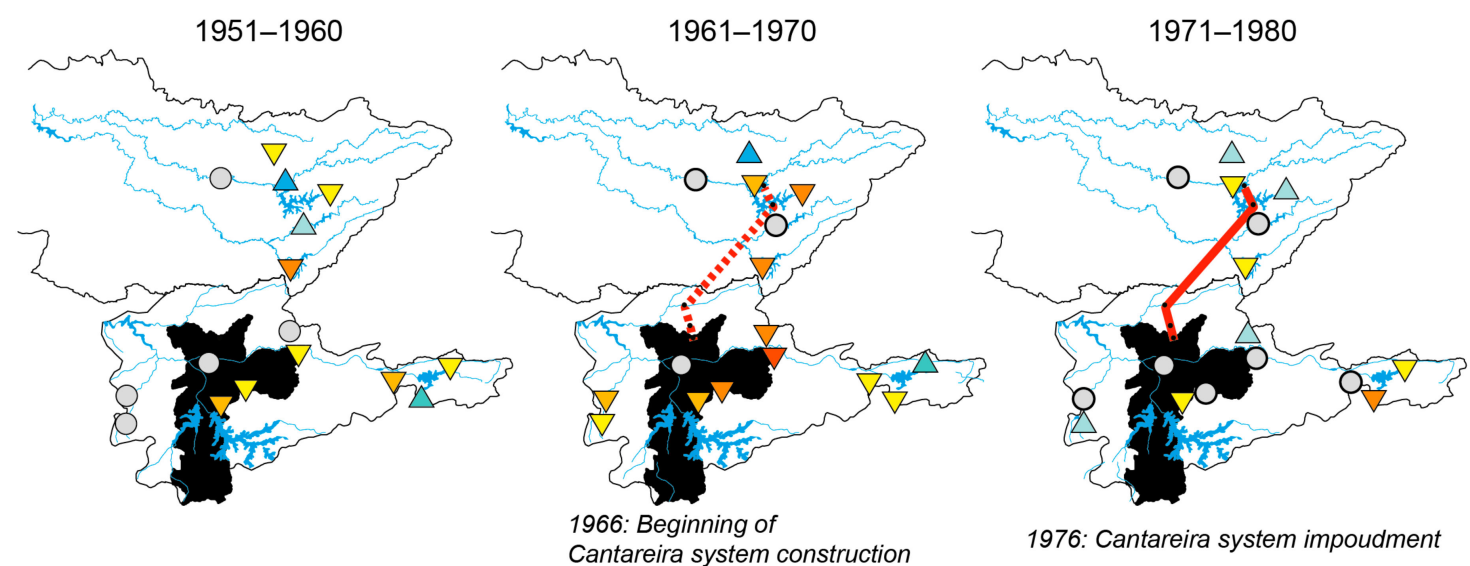

1976: Cantareira system impoudment
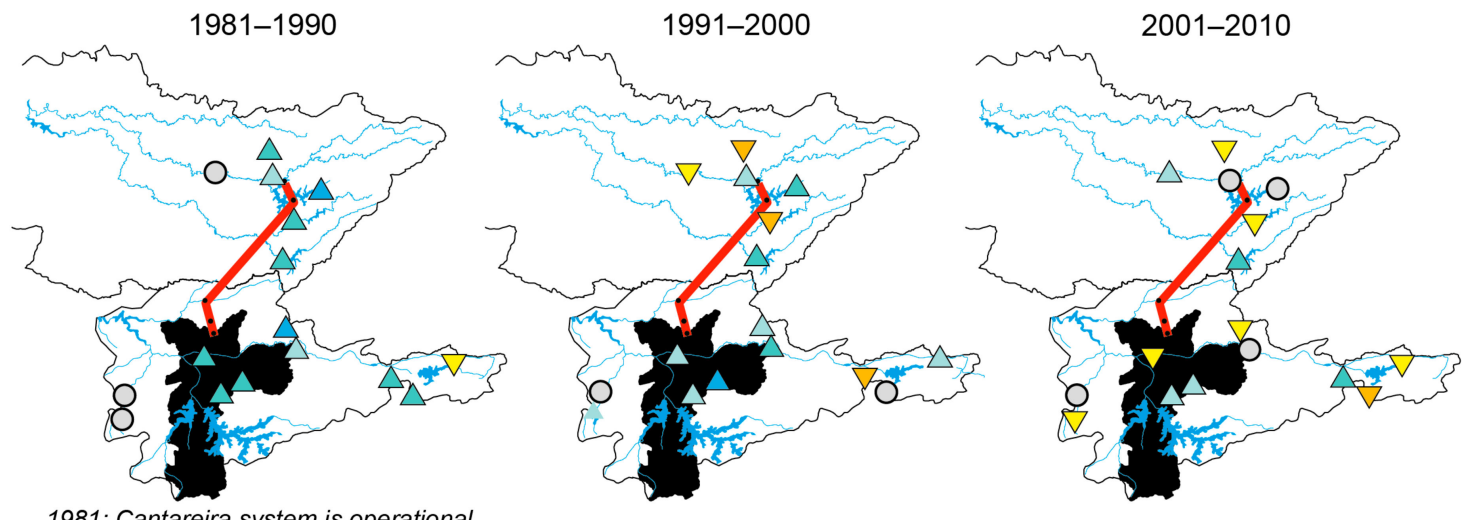

1981: Cantareira system is operational
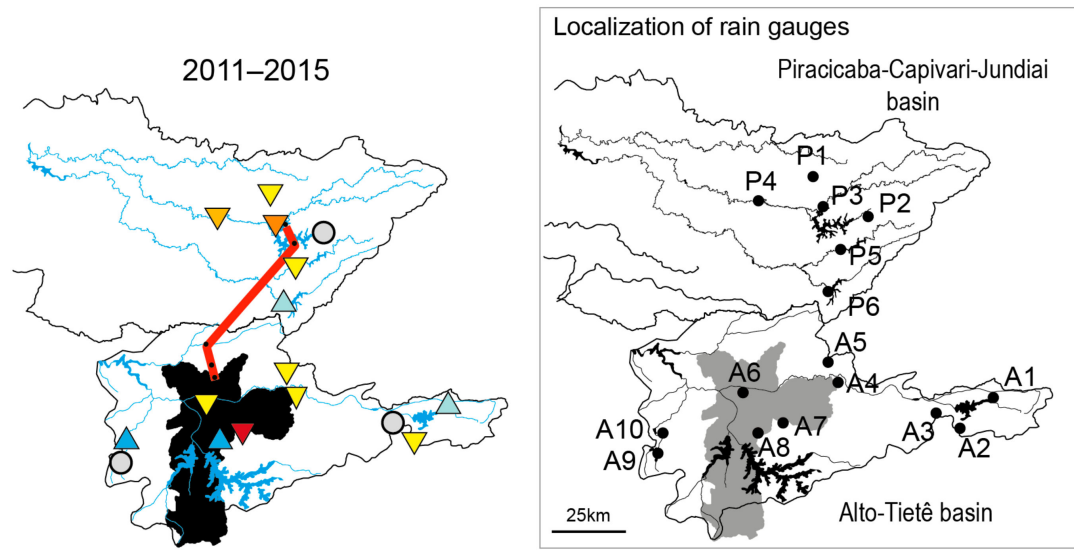

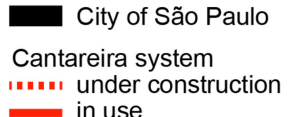

in use

Standardized Precipitation Index value at rain gauges

\begin{tabular}{|c|c|}
\hline 1.0 & $\bigcirc^{0.1}$ \\
\hline 0.9 & $\nabla^{-0.1}$ \\
\hline 0.7 & -0.3 \\
\hline 0.5 & -0.5 \\
\hline 0.3 & $\nabla^{\nabla}-0.7$ \\
\hline 0.1 & $\nabla-0.9$ \\
\hline
\end{tabular}

Figure 5. Decadal standardized precipitation index (SPI) based on annual SPI values computed for each rain gauges of the Alto-Tietê basin and the headwaters of the PCJ basin for the 1951-2015 period.

\subsection{Precipitation Anomalies Since 1951}

Based on the threshold level approach, the number of precipitation anomalies that affected the Alto-Tietê and PCJ basins was assessed. On average, 16 precipitation drought events occurred each decade (not shown). The highest number of episodes was observed during the 1961-1970 decade, with 19 drought events. The mean duration and mean deficit of precipitation anomalies was then addressed and are presented at a decadal time step in Figure 6.

According to Figure 6, the length and deficit volumes of precipitation volumes are homogeneous through time over both basins. With regard to the Alto-Tietê basin, precipitation anomalies last on average between 28 and 40 days and the mean deficit volume vary between $16 \mathrm{~mm}$ and $30 \mathrm{~mm}$. Considering the headwaters of the PCJ basin, precipitation anomalies last on average between 27 and 43 days and the mean deficit volume vary between $16 \mathrm{~mm}$ and $35 \mathrm{~mm}$. Nonetheless, it can be seen that 
the precipitation anomalies of the 2001-2010 decade had the lowest deficit volumes (less than $16.5 \mathrm{~mm}$ ) on average in both catchments. Finally, still from Figure 6, it can be underlined that precipitation anomalies of the 2011-2015 period lasted for a longer period in the Alto-Tietê basin than in the headwaters of the PCJ basin, although the difference remains small (31.5 and 29 days on average, respectively). Volume deficits were nonetheless larger in the headwaters of the PCJ basin than in the Alto-Tietê basin: $34.5 \mathrm{~mm}$ and $21.9 \mathrm{~mm}$ on average, respectively. Finally, it can be noted that P5, situated close to the Jacarei reservoir, recorded the longest and driest precipitation anomalies during this period (mean duration of 51 days and mean volume deficit of $65.6 \mathrm{~mm}$; Figure 6).
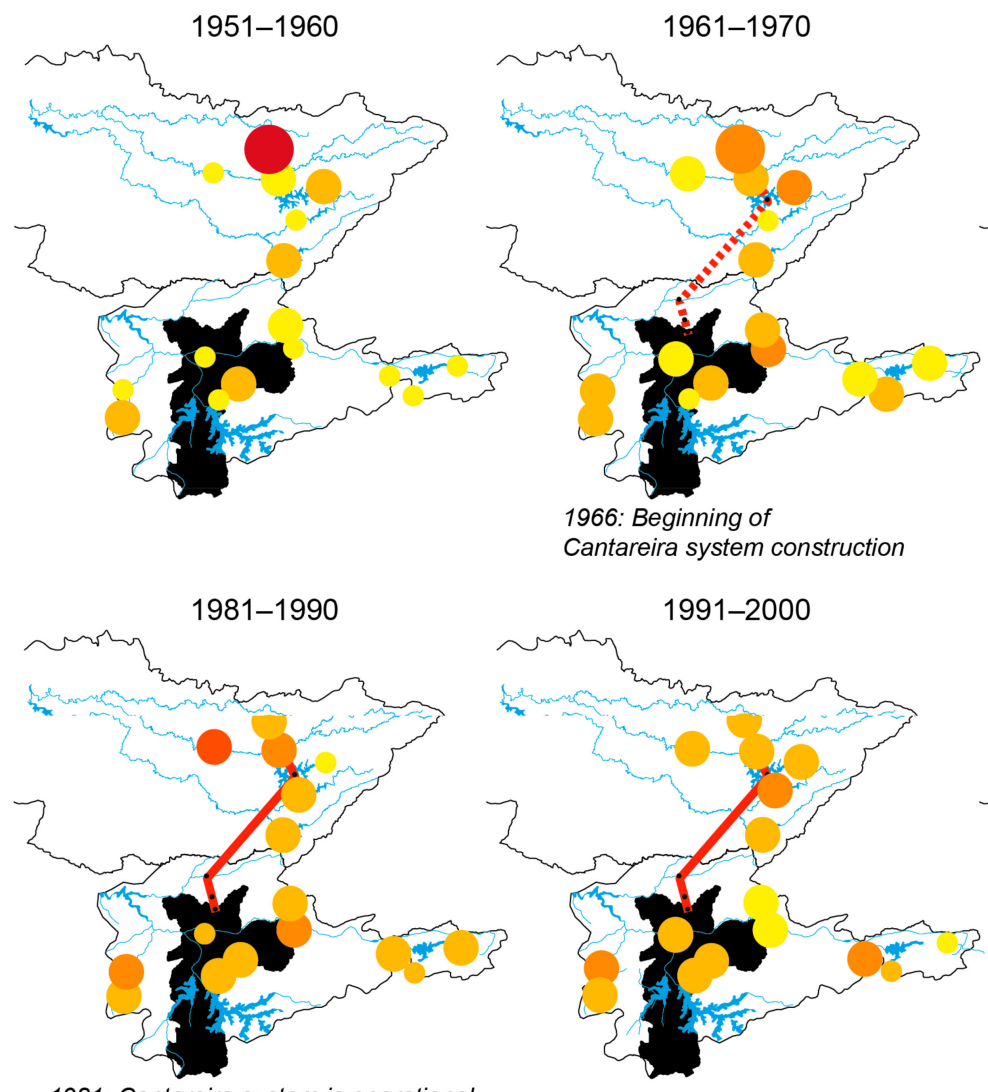

1981: Cantareira system is operational

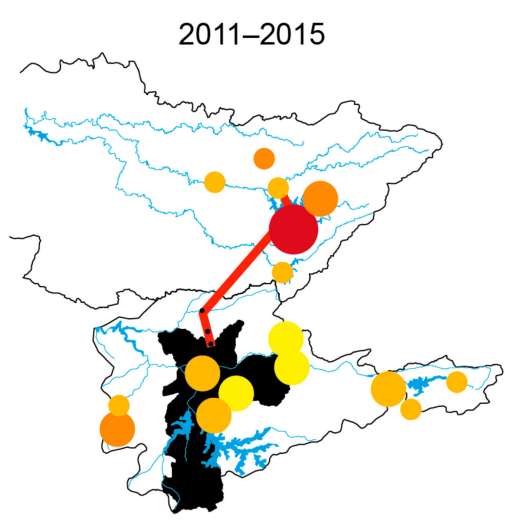

1966: Beginning of

Cantareira system construction
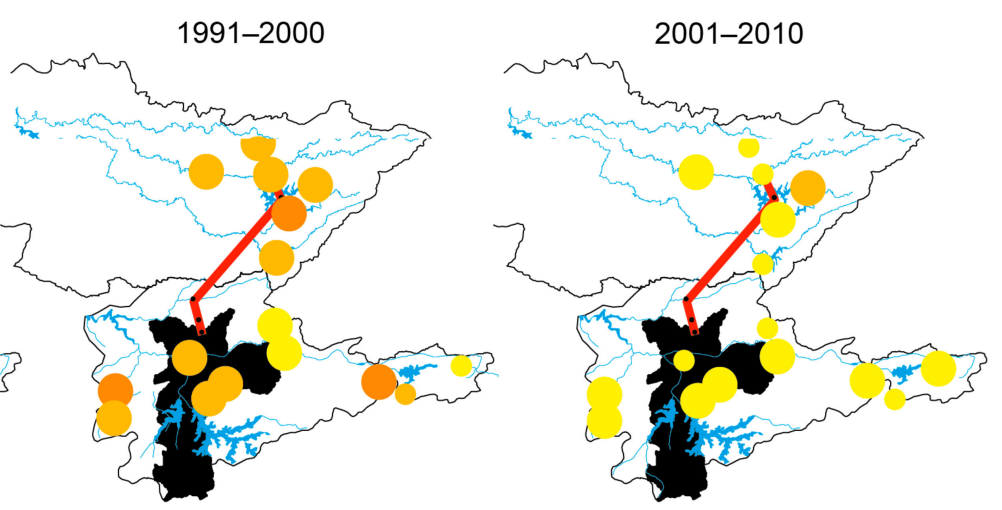

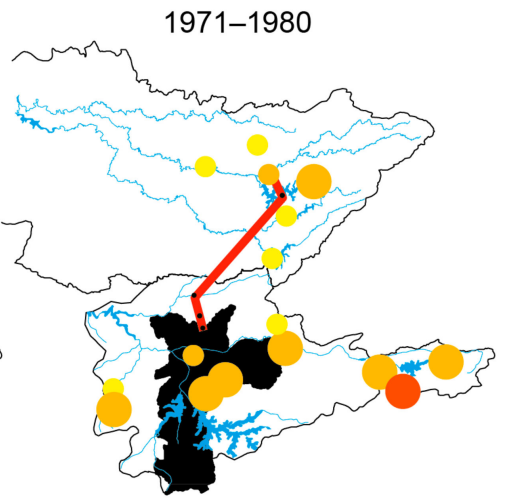

1976: Cantareira system impoudment

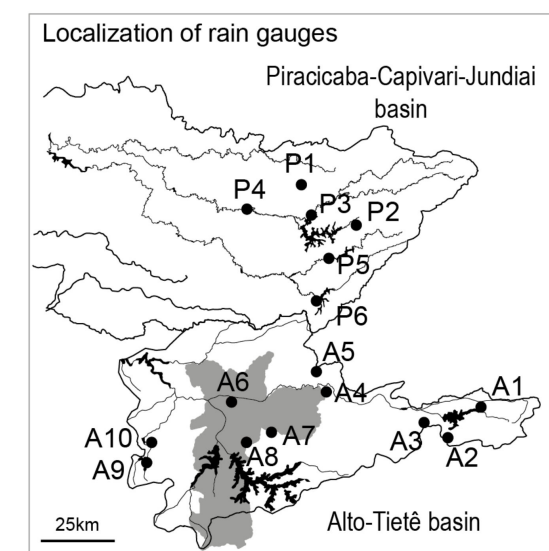

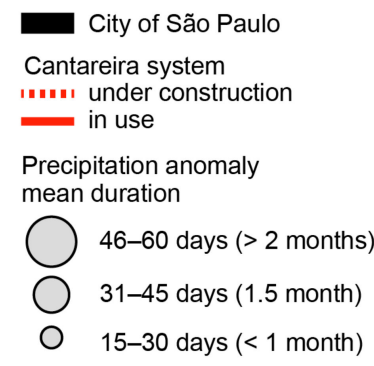

Precipitation anomaly mean deficit $(\mathrm{mm})$

$\begin{array}{lllll}50 & 40 & 30 & 20 & 10\end{array}$

Figure 6. Mean duration (circles) and mean deficit (color gradient) of precipitation anomalies in the Alto-Tietê basin and the headwaters of the PCJ basin during the 1951-2015 period, averaged at a decadal time-step. 


\subsection{Hydrological Anomalies Since 1951}

\subsubsection{Thresholds to Pinpoint the Severity of Hydrological Droughts}

Table 1 presents the results from the low-flow frequency analysis. The Weibull and GEV distributions best fitted runoff series of the Alto-Tietê and PCJ rivers. It also resulted from this analysis that the 7Q2 and 7Q10 thresholds corresponded to a return period of observed 7-day flow minima of 98 and 99 years, respectively.

Table 1. Best-fit probability functions of low flow series and extreme low flow thresholds.

\begin{tabular}{cccc}
\hline Monitored River & Best-Fit Distribution & $\begin{array}{c}\text { 7Q2 (m3/s) } \\
\text { Return Period: 98 Years }\end{array}$ & $\begin{array}{c}\text { 7Q10 (m3/s) } \\
\text { Return Period: 99 Years }\end{array}$ \\
\hline Alto-Tietê & Weibull & 4.0 & 1.5 \\
Camanducaia & GEV & 2.1 & 1.2 \\
Jaguari & Weibull & 4.6 & 1.2 \\
Atibaia & GEV & 1.0 & 0.4 \\
Capivari & GEV & 1.6 & 0.8 \\
\hline
\end{tabular}

\subsubsection{Hydrological Droughts in the Alto-Tietê Basin}

Based on the threshold level approach, hydrological droughts were identified and characterized by their mean duration and mean deficit (Table 2). The temporal comparison between monthly observed runoff values and the three threshold values used to characterize the intensity of hydrological drought episodes are presented in Figure 7.

For the Alto-Tietê River, the largest number of hydrological drought events were observed during the 2001-2010 decade (Table 2). Each year of this decade was affected by one to four hydrological droughts. The longest episodes occurred in 2003 and 2005: they respectively lasted 258 and 223 days and enhanced a volume deficit of $265.8 \mathrm{~m}^{3}$ and $273.3 \mathrm{~m}^{3}$, i.e., a loss in discharge of 1-1.2 $\mathrm{m}^{3}$ per day. In 2003 and 2005, monthly runoff values were often lower than the 7Q2 threshold (Figure 7a). The highest volume deficits were nonetheless recorded in 2006 and $2007\left(361.1 \mathrm{~m}^{3}\right.$ and $295.9 \mathrm{~m}^{3}$, respectively). These drought episodes occurred over shorter periods of time (178 and 147 days, respectively) causing a mean discharge deficit of $2 \mathrm{~m}^{3}$ per day. In 2006, mean monthly runoff fell below the 7Q10 threshold between May and August (Figure 7a).

Table 2. Decadal characteristics of hydrological drought events that affected the Alto-Tietê, Camanducaia and Capivari rivers.

\begin{tabular}{|c|c|c|c|c|c|c|c|c|c|}
\hline & \multicolumn{3}{|c|}{ Alto-Tietê River } & \multicolumn{3}{|c|}{ Camanducaia River } & \multicolumn{3}{|c|}{ Capivari River } \\
\hline & $\begin{array}{c}\text { Total } \\
\text { Drought } \\
\text { Events }\end{array}$ & $\begin{array}{c}\text { Mean } \\
\text { Duration } \\
\text { (days) }\end{array}$ & $\begin{array}{c}\text { Mean } \\
\text { Deficit } \\
\left(\mathrm{m}^{3}\right)\end{array}$ & $\begin{array}{l}\text { Total } \\
\text { Drought } \\
\text { Events }\end{array}$ & $\begin{array}{l}\text { Mean } \\
\text { Duration } \\
\text { (days) }\end{array}$ & $\begin{array}{c}\text { Mean } \\
\text { Deficit } \\
\left(\mathrm{m}^{3}\right)\end{array}$ & $\begin{array}{l}\text { Total } \\
\text { Drought } \\
\text { Events }\end{array}$ & $\begin{array}{l}\text { Mean } \\
\text { Duration } \\
\text { (days) }\end{array}$ & $\begin{array}{c}\text { Mean } \\
\text { Deficit } \\
\left(\mathrm{m}^{3}\right)\end{array}$ \\
\hline 1951-1960 & NA & NA & NA & 19 & 54 & 39.3 & 13 & 99 & 81.7 \\
\hline 1961-1970 & 5 & 26 & 18.7 & 8 & 107 & 131.2 & 16 & 73 & 62.2 \\
\hline 1971-1980 & 12 & 28 & 30.7 & 7 & 36 & 27.8 & 22 & 41 & 28.7 \\
\hline 1981-1990 & 0 & - & - & 11 & 29 & 13.7 & 6 & 49 & 24.8 \\
\hline 1991-2000 & 3 & 38 & 28.1 & 10 & 40 & 20.3 & 1 & 38 & 11.3 \\
\hline 2001-2010 & 23 & 103 & 142.1 & 9 & 46 & 18.4 & 0 & - & - \\
\hline 2011-2015 & 6 & 154 & 252.9 & 8 & 138 & 271.4 & 1 & 22 & 8.9 \\
\hline
\end{tabular}

Finally, the 2011-2015 period was characterized by low runoff series. Monthly runoff was lower than the 7Q2 threshold during the austral winter 2012 (June to September) and the 7Q10 threshold in spring 2013 (September to December; Figure 7a). In 2014, the longest and driest drought event of the 1965-2015 period was identified. It lasted 333 days and enhanced a total volume deficit of $631.5 \mathrm{~m}^{3}$, 
i.e., a loss in discharge of $1.9 \mathrm{~m}^{3}$ per day on average. This same year, runoff values were below the 7Q2 threshold, and even below the 7Q10 in November (Figure 7a).

(a) Alto-Tietê River

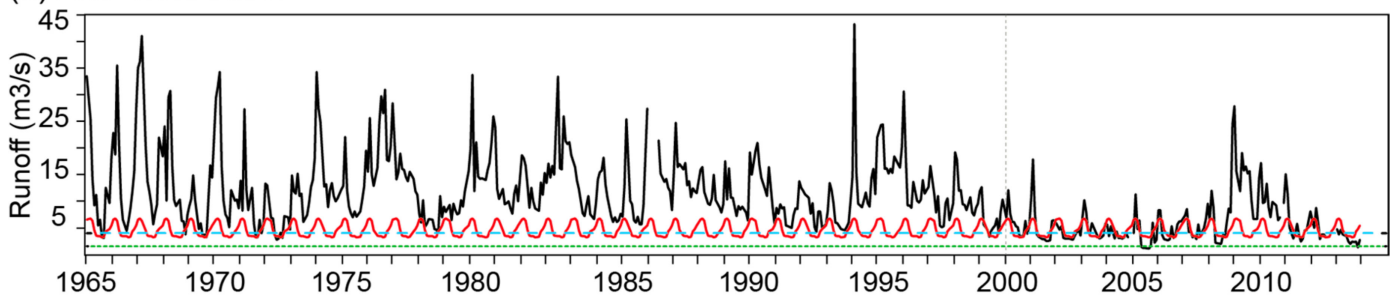

(b) Camanducaia River

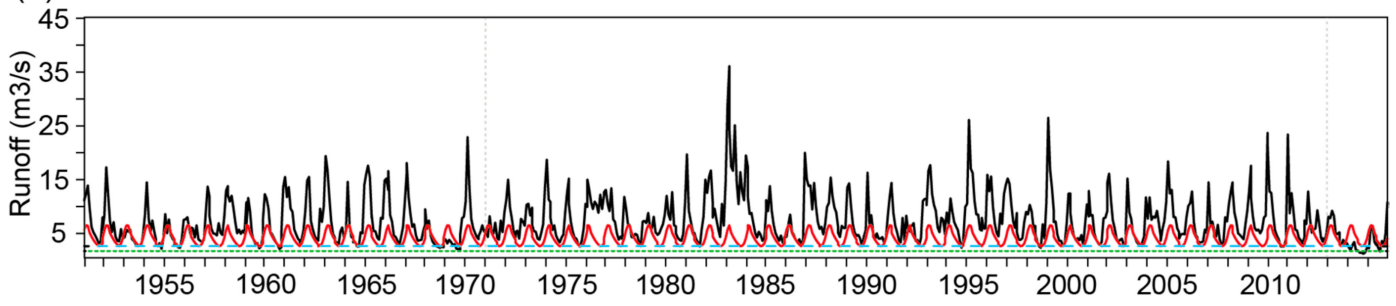

(c) Capivari River

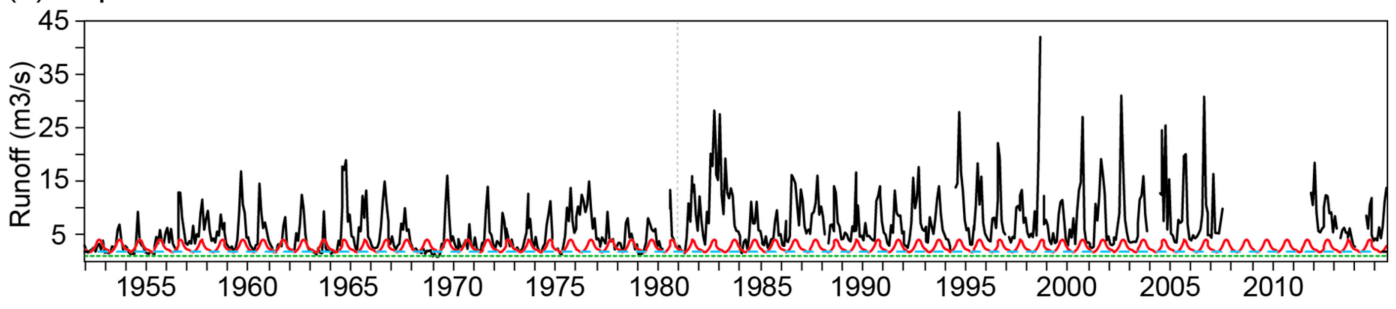

(d) Jaguari River (downstream the Jaguari and Jacarei reservoirs)

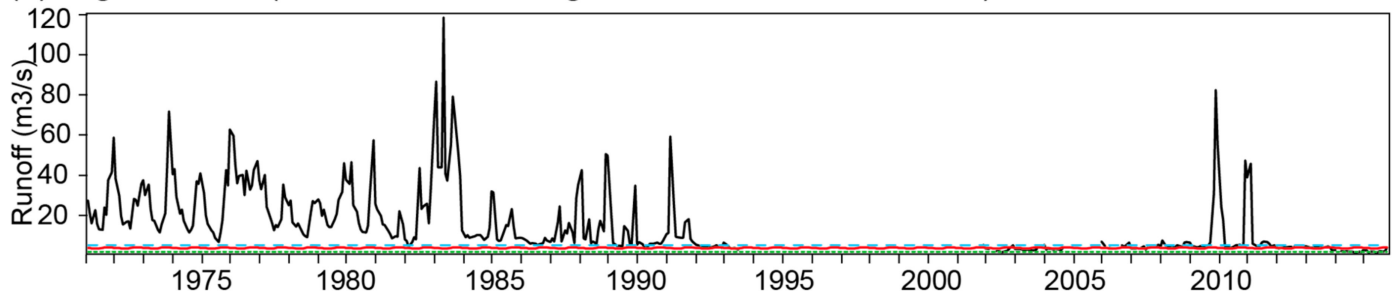

(e) Atibaia River (downstream Cachoeira reservoir)

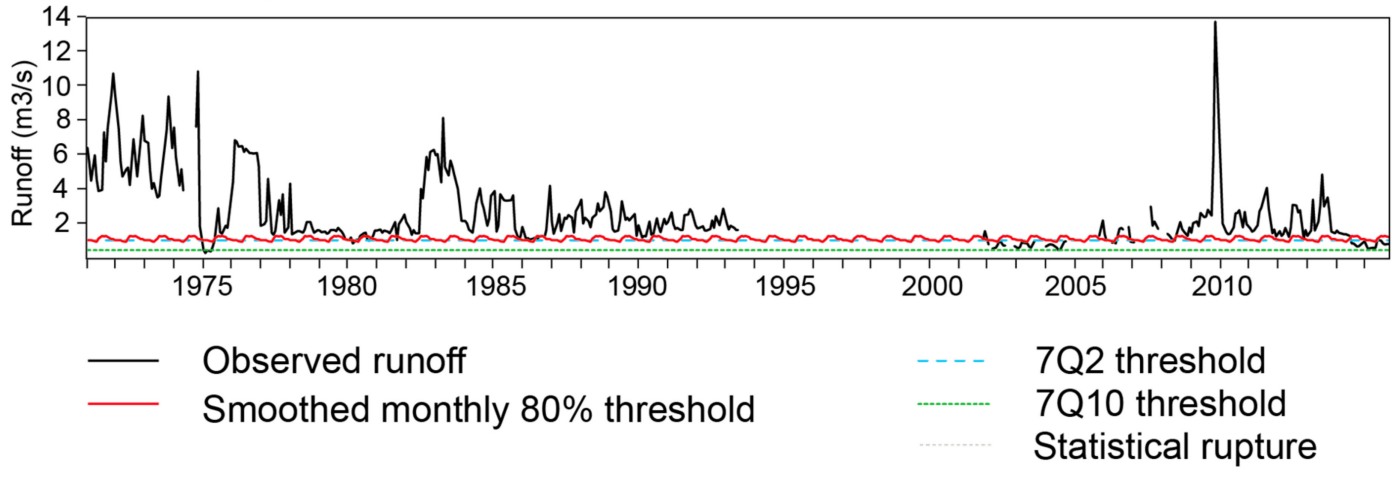

Figure 7. Observed monthly runoff series of the Alto-Tietê River (Alto-Tietê basin) and the Camanducaia, Capivari, Jaguari and Atibaia rivers (PCJ basin) compared to three threshold values (80th percentile of monthy flow duration curves, 7Q2 and 7Q10) in order to capture hydrological anomalies (i.e., when observed runoff values are lower than the threshold values). Statistical ruptures identified in Section 4.2 are also shown. 


\subsubsection{Hydrological Droughts in the Headwaters of the PCJ Basin}

Regarding the Camanducaia River, the longest and driest drought events were observed during the 1961-1970 decade and 2011-2015 period. The most severe episodes were recorded in 1968, 1969, and 2015. Their respective durations were 138 days, 263 days and 125 days. During the austral winter season (July to September), daily runoff values failed to meet the 7Q2 threshold (Figure 7b), leading to total volume deficits of $113.9 \mathrm{~m}^{3}, 453.7 \mathrm{~m}^{3}$, and $218.2 \mathrm{~m}^{3}$, respectively (i.e., a mean discharge deficit of $0.8-1.7 \mathrm{~m}^{3}$ per day during the drought episodes). The drought event that occurred in 2014 was even more extreme. It lasted 356 days and triggered an annual volume deficit of $812.5 \mathrm{~m}^{3}$, i.e., a loss in discharge of $2.3 \mathrm{~m}^{3}$ per day. From August to November, daily runoff values fell below the 7Q2 threshold (Figure $7 \mathrm{~b}$ ).

The Capivari River was mostly concerned by hydrological droughts before 1980 (Table 2 and Figure 7c). The first most severe runoff anomaly was observed in 1953. It lasted 288 days, the volume deficit reached $256 \mathrm{~m}^{3}$ (i.e., a loss in discharge of $0.9 \mathrm{~m}^{3}$ per day) and daily runoff values were regularly lower than the 7Q2 threshold between July and December (Figure 7c). The second most severe runoff anomaly was observed in 1969 during 296 days. A total volume deficit of $417.5 \mathrm{~m}^{3}$ was estimated, i.e., a loss in discharge of $1.4 \mathrm{~m}^{3}$ per day during the drought episode, noted by daily runoff values lower than the 7Q10 threshold during autumn (April to June) and winter (July to September; Figure 7c).

Finally, runoff anomalies were difficult to analyze for the Jaguari and Atibaia rivers, on one hand because of a significant number of gaps in the dataset (Figure 2), and on the other hand because they have been implemented downstream the main reservoirs that compose the Cantareira system. Runoff values are hence influenced and depend on management options considered by SABESP. Nonetheless, it can still be observed that runoff values are below the 7Q2 value from November 2011 for the Jaguari River, downstream the Jaguari and Jacarei reservoirs (first reservoirs of the Cantareira system; Figure 7d), and from September 2014 for the Atibaia River, downstream the Atibainha reservoir (fourth reservoir of the system; Figure 7e). In addition, such low runoff values downstream these reservoirs were already observed between January 2002 and September 2009 for the former, and between January 2002 and August 2006 for the latter (Figure 7d,e).

\section{Discussion}

\subsection{Overview of Precipitation and Runoff Long-Term Trends}

The historical records and statistical analysis revealed that the Alto-Tietê basin and the headwater of the PCJ basin were affected by several dry spells during the 1951-2015 period.

The most severe precipitation anomalies were recorded during the 1961-1970 decade and 2011-2015 period. Precipitation deficits often lasted for more than 45 days and more than $80 \%$ of dry days belonged to a dry event of at least seven days during the dry season. Episodes that occurred in 1963 and 1968 were particularly persistent. They lasted for more than three months and annual precipitation were $25-35 \%$ below normal values due to more low intensity events in the Alto-Tietê basin and a decrease in the number of wet days in both basins. The most severe hydrological anomaly identified for the Camanducaia and Capivari rivers was notably observed in 1968 and 1969, respectively. River flows were lower than the 7Q2 threshold, and even the 7Q10 threshold for the Capivari River, during the austral winter.

In addition, a hydrological drought was identified between 2003 and 2006 in the Alto-Tietê basin, certainly explaining the statistical rupture observed in the runoff series in 2000. A return period of 99 years was notably identified for river flows during the austral winter 2006. During this same period, runoff deficits were observed at the outlet of the reservoirs of the Cantareira system. This is probably the consequence of less wet days, although with low volume deficits, that enhanced several short dry periods during the wet season of the 2001-2010 decade.

Therefore, the water supply basins of SPMR have been affected by severe hydro-climatic drought events during the 1951-2010 period but with reduced magnitude and duration $[18,19]$. These previous 
events notably resulted in the development of the Cantareira System in the late 1960s but, to our knowledge, episodes identified during the 2000 decade resulted in an energy crisis but not a water crisis [65-67].

\subsection{Overview of the Hydro-Climatic Context of the 2011-2015 Water Crisis}

The 2011-2015 period was characterized by severe precipitation anomalies and runoff deficits that concerned the north of the Alto-Tietê basin and the headwaters of the PCJ basin. The southern part of the Alto-Tietê basin was poorly affected, most certainly in relationship with isolated topographic features modulated by Serra do Mar and Serra da Paranapiacaba $[19,68]$. During this period, the north of the Alto-Tietê basin was affected by a large number of days without rain that resulted in a long dry season, until mid-November, while precipitation had a greater volume deficit in the headwaters of the PCJ basin due to less intense precipitation events. In addition, during the driest month, August $70-80 \%$ and $80-90 \%$ of dry days belonged to a dry event of at least seven days in the Alto-Tietê and headwaters of the PCJ basins, respectively, and 40\% of dry days observed in October and November still belonged to dry events of at least seven days.

The peak of the crisis can be defined when there was a significant breakdown in water supply. It started during the austral spring 2013 when monthly runoff values fell below the 7Q10 at the outlet of the Jaguari and Jacarei reservoirs as well as in the Camanducaia and Alto-Tietê rivers. A decrease in annual runoff by two and a half time was even observed since then for the Camanducaia River. This period was followed by the longest and driest hydrological drought of the 1951-2015 period. It lasted almost a year and triggered a loss in runoff of $1.9 \mathrm{~m}^{3} /$ day and $2.3 \mathrm{~m}^{3}$ / day in the Alto-Tietê and Camanducaia rivers, respectively, in 2014. Both rivers had runoff values below the 7Q2 threshold and, at times, lower than the 7Q10 threshold, during the year 2014 for the former, and from August to November 2014 for the latter. The low-flow frequency analysis revealed that runoff values observed during the austral spring 2013 and the year 2014 had a return period of 98 years.

During the dry austral winter (July to September) and spring (October to December) in 2013, precipitation were $44 \%$ and 15\% below the seasonal 1951-2010 norm in the north of the Alto-Tietê basin, and $15 \%$ and $25 \%$ below the seasonal 1951-2010 norms in the headwaters of the PCJ basin, respectively. In 2014, annual precipitation records were $44 \%$ below the seasonal norm values. These results are in line with previous studies that diagnosed that the austral summer 2013/2014 and the year 2014 stand out as the driest of the 1961-2015 records [7,18,19]. According to Coelho et al. (2015), the probability of attaining such precipitation levels was of $0.01 \%$ [19]. This illustrates how rare this hydro-climatic event was.

\subsection{Coping With the Risk of Water Crisis}

During the past 70 years, several hydro-climatic droughts affected the water supply basins of SPMR. Changes in precipitation seasonality had a significant impact on the availability of water resources in the water supply basins and, in a context of demographic and socio-economic growth, led to a water crisis in 2013-2015. In light of climate change, temperatures, rainfall extremes and the number of consecutive dry days are projected to increase in Southern and Southeastern Brazil by 2030 [69]. Hydrological droughts are then likely to happen again in the near future.

To cope with water scarcity risks, water supply structural measures are further developed by the SABESP (Jerson Kelman, personal communication, 8 August 2016). Since 2009, the SABESP operates a wastewater treatment and reuse plant for industrial purposes, and since 2013, it invests into three main projects to store larger amounts of water (Jerson Kelman, personal comm., 8 August 2016): (1) the São Lourenço water production system that aims to raise water supply by $7 \%$ for the SPMR, especially in the west of the metropolis; (2) the interconnection between the Jaguari and Atibainha reservoirs of the Cantareira system; and (3) the Itapanhau project (not started yet) that aims to transfer water from the Paraiba do Sul mountains to the Alto-Tietê River. However, counterpoints to infrastructural approaches are advanced by some authors calling for new measures for SPMR see 
e.g., $[40,70,71]$. In particular, they promote economic demand management mechanisms that proved successful in arid regions, like the water pricing incentives set during the 2013-2015 water crisis yet abandoned once the critical period was over, or water rights trade and adaptation for less thirsty and higher added value crops implemented in Brazil's northeastern state Ceara. Other authors also encourage moving towards local solutions and rainwater harvest $[30,72,73]$ or catchment protection options [74-76]. All agree that, in a changing environment, there is a need for water authorities and its population to raise awareness about limited freshwater resources.

\section{Conclusions}

Based on the analysis of data from 16 rain-gauge stations and 5 runoff-gauging stations located in the Alto-Tietê basin and the headwaters of the PCJ basin that supply water to SPMR, we examined the long-term trends of precipitation and runoff records to address the severity of the 2013-2015 drought. Our analysis showed that the hydro-climatic drought concerned the north of the Alto-Tietê basin and the headwaters of the PCJ basin. Both areas were affected by a deficit in precipitation from the austral spring 2013 to the end of the year 2014 due to a large number of wet days without rain in the north of the Alto-Tietê basin and to less intense precipitation events in the headwaters of the PCJ basin. Our use of the threshold level method showed that from the austral spring 2013 to the austral summer 2014, low flows were extreme and, consequently, we assume that they did not allow to correctly fill in the reservoirs of the Cantareira system, and to fulfill water demands depending on reservoirs with very low levels. Observed precipitation had a probability of occurrence $0.01 \%$ [19] and observed runoff had a return period of 98 years, and, at time, of 99 years (this study), which highlight the rare nature of this long-lasting phenomenon. Nonetheless, considering climatic and anthropogenic changes, the SPMR remains particularly vulnerable to water scarcity events. There is an urgent need for water authorities to be aware of this risk and to implement efficient hydraulic infrastructures and water saving policies.

Author Contributions: Conceptualization: M.M., E.R. and J.G.; Methodology, Formal Analysis, Visualization and Writing-Original Draft Preparation: M.M.; Data curation: M.M. and G.M.-M.; Investigation: J.G., M.M., G.M.-M. and E.R.; Writing-Review \& Editing: E.R., G.M.-M. and J.G.; Supervision and Project Administration: E.R.

Funding: This research was funded by the Faculty of Geosciences and Environment of the University of Lausanne (investment funds).

Acknowledgments: The authors would like to acknowledge the Departamento de Águas e Energia Elétrica (DAEE) of São Paulo State and the National Water Agency (Agência Nacional de Águas, ANA) for providing all the necessary data to realize this research. The authors are also grateful to Jerson Kelman, director of SABESP from 2015 to 2018, for offering his valuable time to discuss about São Paulo's water crisis.

Conflicts of Interest: The authors declare no conflicts of interest.

\section{References}

1. OECD—Organisation for Economic Cooperation and Development. Governança dos Recursos hídricos No Brasil; OECD Publishing: Paris, France, 2015; ISBN 978-92-64-23816-9.

2. FAO-Food and Agriculture Organization of the United Nations. AQUASTAT Main Database, Food and Agriculture Organization of the United Nations (FAO). Available online: http:/ / www.fao.org/nr/water/ aquastat/data/query/ (accessed on 9 August 2018).

3. ANA—Agência Nacional de Aguas. Conjuntura dos Recursos Hídricos No Brasil: Regiões hidrográficas Brasileiras. Edição Especial; Agência Nacional de Aguas, Ministéria do Meio Ambiente: Brasília, Brazil, 2015; 162p, ISBN 978-85-8210-027-1.

4. ANA-Agência Nacional de Aguas. Encarte Especial Sobre a Crise Hídrica. Conjuntura dos Recursos Hídricos No Brasil; Agência Nacional de Aguas, Ministéria do Meio Ambiente: Brasília, Brazil, 2015; 31p.

5. Jacobi, P.; Cibim, J.; Leão, R. Crise na macrometrópole paulista e respostas da sociedade civil. Estudos Avançados 2015, 29, 27-42. [CrossRef]

6. Getirana, A. Extreme water deficit in Brazil detected from space. J. Hydrometeorol. 2016, 17, 591-599. [CrossRef] 
7. Nobre, C.; Marengo, J.; Seluchi, M.; Cuartas, A.; Alves, L. Some characteristics and impacts of the drought and water crisis in Southeastern Brazil during 2014 and 2015. J. Water Resour. Protect. 2016, 8, 252-262. [CrossRef]

8. Soriano, E.; Londe, L.; Di Gregorio, L.; Coutinho, M.; Santos, L. Water crisis in São Paulo evaluated under the disaster's point of view. Ambiente Soc. 2016, XIX, 21-39. [CrossRef]

9. Emplasa. Região Metropolitana de São Paulo. Available online: https://www.emplasa.sp.gov.br/RMSP (accessed on 9 August 2018).

10. Cortes, P.; Torrente, M.; Filho, A.; Ruiz, M.; Dias, A.; Rodrigues, R. Crise de abastecimento de água em São Paulo e falta de planejamento estratégico. Estudos Avançados 2015, 29, 7-26. [CrossRef]

11. Gerberg, J. A Megacity without water: São Paulo's drought. Time, 13 October 2015. Available online: http:/ / time.com/4054262/drought-brazil-video/(accessed on 9 August 2018).

12. Romero, S. Taps start to run dry in Brazil's largest city. São Paulo water crisis linked to growth, pollution and deforestation. The New York Times, 16 February 2015. Available online: https://www.nytimes.com/ 2015/02/17/world/americas/drought-pushes-sao-paulo-brazil-toward-water-crisis.html (accessed on 9 August 2018).

13. Lobel, F. Sistema Cantareira passa a ter faixas de segurança contra períodos de seca. Folha de S.Paulo, 31 May 2017. Available online: https://www1.folha.uol.com.br/cotidiano/2017/05/1889154-sistemacantareira-passa-a-ter-faixas-de-seguranca-contra-seca.shtml (accessed on 9 August 2018).

14. fsfdssssssssss Stefano, D. Governo de São Paulo não aprendeu com a crise da água, afriman especialitas. Modelo de gestão dos recursos hídricos continua inalterado desde os primeiros sinais de desabastecimento. Brasil de Fato, 22 March 2017. Available online: https:/ /www.brasildefato.com.br/2017/03/22/governo-deSao-paulo-nao-aprendeu-com-a-crise-da-agua-afirmam-especialistas/ (accessed on 9 August 2018).

15. Seth, A.; Fernandes, K.; Camargo, S. Two summers of São Paulo drought: Origins in the western tropical Pacific. Geophys. Res. Lett. 2015, 42, 10-816. [CrossRef]

16. Silva, W.; Nascimento, M.; Menezes, W. Atmospheric blocking in the South Atlantic during the summer 2014: A synoptic analysis of the phenomenon. Atmos. Clim. Sci. 2015, 5, 386-393. [CrossRef]

17. Oliveira, F.; Carvalho, L.; Ambrizzi, T. A new climatology for southern hemisphere blockings in the winter and the combined effect of ENSO and SAM phases. Int. J. Climatol. 2014, 34, 1676-1692. [CrossRef]

18. Coelho, C.; De Oliveira, C.; Ambrizzi, T.; Rebolta, M.; Carpenedo, C.; Campos, J.; Tomaziello, A.; Pampuch, L.; Custodio, M.; Dutra, L.; et al. The 2014 southeast Brazil austral summer drought: Regional scale mechanisms and teleconnections. Clim. Dyn. 2016, 46, 3737-3752. [CrossRef]

19. Coelho, C.; Cardoso, D.; Firpo, M. Precipitation diagnostics of an exceptionally dry event in São Paulo, Brazil. Theor. Appl. Climatol. 2015, 125, 769-784. [CrossRef]

20. SABESP - Companhia de Saneamento Basico do Estado de Sao Paulo. Sustainability Report 2014; SABESP: São Paulo, Brazil, 2014.

21. Coutinho, R.; Kraenkel, R.; Prado, P. Catastrophic regime shift in water reservoirs and São Paulo water supply crisis. PLoS ONE 2015, 10, e0138278. [CrossRef] [PubMed]

22. IBGE-Instituto Brasileiro de Geografia e Estatística. São Paulo. Produto Interno Bruto dos Municípios 2015. Available online: http:/ / cod.ibge.gov.br/ (accessed on 9 August 2018).

23. CETESB - Companhia Ambiantal do Estado de São Paulo. Qualidade das águas superficias no estado de São Paulo 2014; CETESB: São Paulo, Brazil, 2015; ISBN 978-85-9467-062-5.

24. Cunha, D.; Sabogal-Paz, L.; Dodds, W. Land use influence on raw surface water quality and treatment costs for drinking supply in São Paulo State (Brazil). Ecol. Eng. 2016, 516-524. [CrossRef]

25. Nobre, A. The Future Climate of Amazonia; Scientific Assessment Report; Articulación Regional Amazônica: São Jose dos Campos, Brazil, 2014; ISBN 978-85-17-00074-4.

26. Dobrovolski, R.; Rattis, L. Water collapse in Brazil: The danger of relying on what you neglect. Nat. Conserv. 2015, 13, 80-83. [CrossRef]

27. Cohen, D. The rationed city: The politics of water, housing and land use in drought-parched São Paulo. Public Cult. 2016, 22, 261-289. [CrossRef]

28. Marengo, J.; Alves, L. Crise hídrica em São Paulo em 2014: Seca e desmatamento. Geousp Espaço e Tempo 2016, 19, 485-494. [CrossRef]

29. De Lima, G.; Lombardo, M.; Magana, V. Urban water supply and the changes in the precipitation patterns in the metropolitan area of São Paulo-Brazil. Appl. Geogr. 2018, 94, 223-229. [CrossRef] 
30. Millington, N. Producing water scarcity in São Paulo, Brazil: The 2014-2015 water crisis and the binding politics of infrastructure. Polit. Geogr. 2018, 65, 26-34. [CrossRef]

31. Otto, F.; Coelho, C.; King, A.; Coughlan de Perez, E.; Wada, Y.; van Oldenborgh, G.; Haarsma, R.; Haustein, K.; Uhe, P.; van Aalst, M.; et al. Factors other than Climate Change, main drivers of 2014/15 water shortage in Southeast Brazil. Bull. Am. Meteorol. Soc. 2015, 96, S35-S40. [CrossRef]

32. Miranda, G.M.; Reynard, E.; Milano, M.; Guerrin, J. Les caractéristiques climatiques de la crise hydrique de 2013-2014 dans la région métropolitaine de São Paulo, Brésil. In Climat et pollution de l'air. In Proceedings of the XXIXe Conference of the "Association Internationale de Climatologie", Besançon, France, 6-9 July 2016; pp. 469-47492018. Available online: http://www.climato.be/aic/colloques.html (accessed on 9 August 2018).

33. Johnson, R.; Kemper, K. Institutional and Policy Analysis of River Basin Management. The Alto-Tietê River basin, São Paulo, Brazil; World Bank Policy Research Working Paper 3650; World Bank: Washington, DC, USA, 2005; 53p.

34. Aparecida de Mello-Théry, N. Conservation of natural areas in São Paulo. Estud. Av. 2011, 25, 175-187. [CrossRef]

35. Bonduki, N. The urban development model of São Paulo needs to be reversed. Estud. Av. 2011, 25, 23-35. [CrossRef]

36. DAEE—Departamento de Aguas e Energia Elétrica. Plano Estadual de Recursos Hídricos 2004/2007. Resumo; DAEE: São Paulo, Brazil, 2007.

37. SEADE—Fundação Sistema Estadual de Análise de Dados. Portal de estatísticas do estado de São Paulo. Available online: http:/ / www.imp.seade.gov.br/frontend/\#/perfil (accessed on 9 August 2018).

38. Consórcio, P.C.J. Sistema Cantareira: Um Mar de Desafios; Consórcio PCJ: São Paulo, Brazil, 2013; $26 \mathrm{p}$.

39. Rodrigues, D.; Gupta, H.; Serrat-Capdevila, A.; Oliveira, P.; Mendiondo, E.; Maddock, T.; Mahmoud, M. Contrasting American and Brazilian systems for water allocation and transfers. J. Water Resour. Plann. Manag. 2014, 140, 04014087-1-04014087-11. [CrossRef]

40. Kelman, J. Water supply to the two largest Brazilian metropolitan regions. Aquat. Proced. 2015, 5, $13-21$. [CrossRef]

41. Erpicum, M.; Binard, M.; Peters, J.P.; Alexandre, J. Une méthode d'analyse des caractéristiques de la saison des pluies en région sahélienne. In Actes des Journées de climatologie. In Proceedings of the Journées de Climatologie, Liège, Belgium, 5-7 November 1987; Erpicum, M., Ed.; Presses Universitaires de Liège: Liège, Belgium, 1987; pp. 43-56.

42. Kouassi, A.; Kouamé, K.; Koffi, Y.; Dje, K.; Paturel, E.; Oulare, S. Analyse de la variabilité climatique et de ses influences sur les régimes pluviométriques saisonniers en Afrique de l'Ouest: Cas du basin versant du N'zi (Bandama) en Côte d'Ivoire. Cybergeo Eur. J. Geography. Environ. Nat. Paysag. 2010, 513, 29. [CrossRef]

43. Pardé, M. Fleuves et Rivières; A. Collin: Paris, France, 1933.

44. Pettitt, A.N. A non-parametric approach to the change-point problem. Appl. Stat. 1979, 28, 126-135. [CrossRef]

45. Lee, A.; Heghinian, S. A shift of the mean level in a sequence of independent normal random variables-A Bayesian approach. Technometrics 1977, 19, 503-506.

46. Buishand, T. Some methods for testing the homogeneity of rainfall records. J. Hydrol. 1982, 58, 11-27. [CrossRef]

47. Hubert, P.; Carbonnel, J.; Chaouche, A. Segmentation des séries hydro et météorologiques. Application à des séries de précipitations et de débits de l'Afrique de l'Ouest. J. Hydrol. 1989, 110, 349-367. [CrossRef]

48. IRD—Institut de Recherche Pour le Développment. KhronoStat Version 1.0; Software IRD: Montpellier, France, 1998; Available online: http:/ / www.hydrosciences.org/spip.php?article1000 (accessed on 9 August 2018).

49. McKee, T.B.; Doesken, N.J.; Kleist, J. The relationship of drought frequency and duration to time scale. In Proceedings of the Eighth Conference on Applied Climatology, Anaheim, CA, USA, 17-22 January 1993; American Meteorological Society: Boston, MA, USA, 1993; pp. 179-184.

50. WMO-World Meteorological Organization. Standardized Precipitation Index User Guide; WMO: Geneva, Switzerland, 2012; ISBN 978-92-63-11091-6.

51. Edwards, D.C.; McKee, T.B. Characteristics of 20th Century Drought in the United States at Multiple Time Scale; Climatology Report 97-2; Department of Atmospheric Science, Colorado State University: Fort Collins, KO, USA, 1997. 
52. Tallaksen, L.; Van Lanen, H. Hydrological Drought: Processes and Estimation Methods for Streamflow and Groundwater; Elsevier: Amsterdam, The Netherlands; Boston, MA, USA, 2004; Volume 48.

53. Van Loon, A.; Van Lanen, H. A process-based typology of hydrological drought. Hydrol. Earth Syst. Sci. 2012, 16, 1915-1946. [CrossRef]

54. Beyene, B.; van Lanen, H.; Torfs, P. Drought Classification, Propagation Analysis and Prediction of Anomalies; Technical Report No. 37; DROUGHT-R\&SPI: Wageningen, The Netherlands, 2015.

55. Van Huijgevoort, M.; Hazenberg, P.; Van Lanen, H.; Uijlenhoet, R. A generic method for hydrological drought identification across different climate regions. Hydrol. Earth Syst. Sci. 2012, 16, 2437-2451. [CrossRef]

56. Wong, G.; Van Lanen, H.; Torfs, P. Probabilistic analysis of hydrological drought characteristics using meteorological drought. Hydrol. Sci. J. 2013, 58, 253-270. [CrossRef]

57. Smakhtin, V. Low flow hydrology: A review. J. Hydrol. 2001, 240, 147-186. [CrossRef]

58. Risley, J.; Stonewall, A.; Haluska, T. Estimating Flow-Duration and Low-Flow Frequency Statistics for Unregulated Streams in Oregon; U.S. Geological Survey Scientific Investigations Report 2008-5126, Revision 1.1; US Geological Survey: Reston, VA, USA, 2009.

59. MathWave. EasyFit-Distribution Fitting Made Easy. Software. Available online: http:/ /www.mathwave. com/en/home.html (accessed on 9 August 2018).

60. Ouarda, T.; Shu, C. Regional low-flow frequency analysis using single and ensemble artificial neural networks. Water Resour. Res. 2009, 45, W11428. [CrossRef]

61. Requena, A.; Ouarda, T.; Chebana, F. Low-flow frequency analysis at ungauged sites based on regionally estimated streamflows. J. Hydrol. 2018, 563, 523-532. [CrossRef]

62. Molugaram, K.; Rao, G. Chapter 9-Chi-Square Distribution. In Statistical Techniques for Transportation Engineering; Molugaram, K., Rao, G., Eds.; Butterworth-Heinemann: Oxford, UK, 2017; pp. 383-413.

63. Stephens, M.A. EDF statistics for goodness of fit and some comparisons. J. Am. Stat. Assoc. 1974, 69, $730-737$. [CrossRef]

64. Masey, F., Jr. The Kolmogorov-Smirnov Test for Goodness of Fit. J. Am. Stat. Assoc. 1951, 46, 68-78. [CrossRef]

65. Simoes, S.; Barros, A. Regional hydroclimatic variability and Brazil's 2001 energy crisis. Manag. Environ. Qual. Int. J. 2007, 18, 263-273. [CrossRef]

66. Franchito, H.; Rao, V.; Barbieri, P.; Santo, C. Rainy-season duration estimated from OLR versus rain gauge data and the 2001 drought in Southeast Brazil. J. Appl. Meteorol. Climatol. 2008, 47, 1493-1499. [CrossRef]

67. Souza, D.; Rodriguez, M.; Reis, D. Crise ernergética 2001: Providencial e reflexiva. Rev. Educ. Tecnol. 2004, 8, 2179-6122.

68. Obregón, G.; Marengo, J.; Nobre, C. Rainfall and climate variability: Long-term trends in the Metropolitan Area of São Paulo in the 20th century. Clim. Res. 2014, 61, 93-107. [CrossRef]

69. Marengo, J. Climate Change and Extreme Events in Brazil; Fundação Brasileira para o Desenvolvimento Sustentável: Rio de Janeiro, Brazil, 2010.

70. Gutiérrez, A.; Engle, N.; De Nys, E.; Molejon, C.; Martins, E. Drought preparedness in Brazil. Weather Clim. Extrem. 2014, 3, 95-106. [CrossRef]

71. Sousa, W.; Baldwin, C.; Camkin, J.; Fidelman, P.; Silva, O.; Neto, S.; Smith, T. Water: Drought, crisis and governance in Australia and Brazil. Water 2016, 8, 493. [CrossRef]

72. Autunes, L.; Thives, L.; Ghisi, E. Potential for potable water savings in buildings by using stormwater harvested from porous pavements. Water 2016, 8, 110. [CrossRef]

73. Teston, A.; Geraldi, M.; Colasio, B.; Ghisi, E. Rainwater harvesting in buildings in Brazil: A literature review. Water 2018, 10, 471. [CrossRef]

74. Araújo, R.; Alves, M.; de Melo, M.; Chrispim, Z.; Mendes, P.; Silva, G., Jr. Water resource management: A comparative evaluation of Brazil, Rio de Janeiro, the European Union, and Portugal. Sci. Total Environ. 2015, 511, 815-828. [CrossRef] [PubMed] 
75. Green, P.; Vörösmarty, C.; Harrison, I.; Farrell, T.; Sáenz, L.; Fekete, B. Freshwater ecosystem services supporting humans: Pivoting from water crisis to water solutions. Glob. Environ. Chang. 2015, 34, 108-118. [CrossRef]

76. Mattos, J.; Santos, D.; Filho, C.; Santos, T.; Santos, M.; Paula, F. Water production in a Brazilian montane rainforest: Implications for water resources management. Environ. Sci. Pol. 2018, 84, 52-59. [CrossRef] 